\title{
The Implementation of Football Sports Coaching Management at Darul Huda Mayak Ponorogo Islamic Boarding School
}

\author{
Brian Kurniawan Widianto $^{1}$, Agus Kristiyanto $^{2}$, Hanik Liskustyawati ${ }^{3}$ \\ ${ }^{1}$ Postgraduate Program in Sport Science, Universitas Sebelas Maret, Surakarta, Indonesia \\ ${ }^{2,3}$ Universitas Sebelas Maret, Surakarta, Indonesia \\ widianto.brian@gmail.com
}

Abstract

Management is an activity process that is efficient, effective, and coordinated to maximize results. Sports management is a combination of management and sports science. Football achievement coaching is carried out at the Darul Huda Mayak Islamic Boarding School, Ponorogo, Indonesia. There is a decrease and an increase in achievement. The purpose of this study was to determine the implementation of football management, the causes of decline and increase in achievement and the obstacles faced from 2015-2020 by the Perasda Achievement Development Team, Darul Huda Mayak Islamic Boarding School. The method used in this research is descriptive qualitative. To find out how the management of football achievement coaching for Darul Huda Mayak, Ponorogo, Indonesia from 20152020. The results of this research team management are very good. In 2015-2020 there was no change in the management of the Persada football team. However, the decline in achievement occurred in 2017 2020 due to the weak ability of the Persada team in terms of penalties, besides that the Persada team's mainstay players had passed and the team split into two teams that took part in the National Santri League in 2018 and 2019.
Keywords implementation; football sports; coaching management;

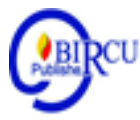

\section{Introduction}

In today's modern era, Islamic boarding schools have become a place of reference for parents to entrust their children. This is done by the parents in the hope that their children will become righteous people who are beneficial to the country and the nation. Through the pesantren, the students will be educated as best as possible for the creation of a generation that will make the nation and state proud in the future. In the world of pesantren education, students are not only equipped with religious knowledge, but also in certain other fields so that it is possible for a santri to be able to increase his interests and talents. One of the trends today is in the field of sports, especially in the field of football.

Darul Huda Islamic boarding school is one of the Islamic boarding schools in Ponorogo which has good achievements in sports, especially football. This proves that Darul Huda Islamic Boarding School is a formal institution which is the right means of channeling talents, interests and potentials in sports and religion. Usually the Islamic boarding schools prioritize the religious direction, but it is different from the Darul Huda Islamic boarding school. This is a plus for Darul Huda Islamic Boarding School, because students can get these two things that are rarely found in other educational institutions.

Based on interviews with the Darul Huda Islamic boarding school sports teacher, many sports that are fostered through extracurriculars include basketball, volleyball, 
badminton, football and table tennis. However, among these various sports, the achievements of the sport of football develop faster than other sports. This is proven by the achievements of the Darul Huda Islamic Boarding School football team which is usually abbreviated as Persada. The Mayak Ponorogo Darul Huda Islamic Boarding School Football Team was the runner up in the 2015 Santri Nusantara League Cup and won the 2017 LSN which was held at the Gelora Bandung Lautan Api Stadium. Darul Huda Mayak boarding school team also won the 2017 East Java Region I National Santri League as a representative team from Ponorogo.

Based on interviews conducted by researchers, the benchmark for achievement of the Persada team was the Nusantara Santri League event or abbreviated as LSN. LSN is a national level football competition whose participants come from Islamic boarding schools throughout Indonesia, after going through the qualifying round. The organizer of this event is Rabithah Ma'ahid Islamiah (RMI) NU in collaboration with the Ministry of Youth and Sports of the Republic of Indonesia. This league was initiated by the General Chairperson of the National Awakening Party DPP, Muhaimin Iskandar and was held for the first time in 2015. The Santri League alumnus who triumphed in the national football arena was Rafli Nursalim who strengthened the Garuda National Team in the AFF 2017. And Darul Huda Islamic boarding school always participated in in the championship from the start of the LSN until today.

In the life of the pesantren, even though the students are required to study religious knowledge every day, they still have free time which they will use for refreshing. Based on observations made by researchers, most of them use their spare time to play football. This is where they learn about togetherness, the importance of solidarity with one another. They also practice and develop their potential. In addition, the games they show are no less interesting than the football players out there. In fact, their abilities may exceed the capabilities of professional football players outside the pesantren. In pesantren, students who have this kind of ability can still increase their potential through various football match events. They can hold friendly matches between pesantren as a form of effort to increase sportsmanship and potential to become athletes. Through events like that, it can also increase brotherhood and friendship between Islamic boarding schools.

Besides some of the strengths and achievements that the Persada team has achieved, there are also several weaknesses that must be fixed and improved. The Persada team experienced a drastic decline in achievement, after winning the 2017 Santri Nusantara League. The data on the achievements of Darul Huda Islamic boarding school football which were obtained during the initial observation, are as follows:

Table 1. Achievements of the Darul Huda Mayak Islamic Boarding School Football Team

\begin{tabular}{c|l|c|l|l}
\hline No. & Year & Champion & \multicolumn{1}{|c}{ Championship } & Information \\
\hline 1 & 2015 & 2 & Liga Santri Nusantara & \\
2 & 2016 & 1 & Regional Santri League & \\
3 & 2017 & 1 & Regional Santri League & \\
& & 1 & Liga Santri Nusantara & \\
4 & 2018 & 1 & Regional Santri League & \\
5 & 2019 & 1 & Regional Santri League & \\
\hline
\end{tabular}


The table above shows the decline in the achievements of the Persada team after winning the 2017 LSN rotating trophy. After winning the 2017 LSN, the Persada team died in the 2018 LSN and only reached the top 8 in 2019 the Persada team won the Regional championship. Judging from human resources from 2017 to 2019, the players and coaches of the Persada team are still the same. This is what makes people question and becomes the public spotlight, especially the supporters of the Persada team.

In the development and achievements achieved by the Persada team, it cannot be separated from the role of the pesantren management itself. Basically sports management is a combination of management and sports science. According to Haris (2020) sports for athletes with special needs have many benefits including improving quality of life, increasing endurance and strength, increasing brain performance, and restoring the mind. Mangolo (2020) states that Sports and Health Physical Education is a learning process through physical activities where each student is obliged to do physical activities to improve his physical fitness. Physical fitness, increased biomotor ability, improved achievement and educational knowledge are the results to be achieved in doing sports activities (Ferdiana, 2020). Management is needed by all organizations, because without management, all efforts will be in vain and the achievement of goals will be more difficult because it is needed to maintain a balance between the conflicting goals, facilities and activities of the interested parties in the organization (Harsuki, 2013: 2). Management has been proven to be one of the supporting factors to achieve the desired goals based on predetermined targets (Sari, 2018).

The management and management system of an organization is very influential on maturity in the development of Islamic boarding schools that are under the organization. Management issues, infrastructure and training administration also need more special attention. Many external and internal factors influence the development of the Darul Huda Islamic boarding school football team. This problem is not a simple problem, but rather a complex problem and must be known in a real way so that the root of the problem can be obtained, so that the problem solving can be done appropriately.

Sustainable achievement is the creation of a good transition system between one generation of athletes with achievements to the next, so that there is no gap between the two generations. For this reason, sports coaching must be arranged in a structured pattern according to the developmental function. This is related to the implementation of management in it. How is it possible to get high achievement if the management of sports management is not good enough, especially without the support of sports facilities and infrastructure that are complete for achievement. Even though the players have high ability and enthusiasm, experienced coaches and international level certification, the management of sports organization management is not good, and without the support of the government, achievements cannot be achieved.

Based on the explanation above, it can be concluded that the problems found can be obtained through research which includes the implementation of management carried out. This research is useful for finding various problems and obstacles in the implementation of football coaching for the Persada team by comparing or comparing the implementation of coaching that was carried out when the Persada team reached the peak of achievement to the decline in achievement. This reason is a trigger for the interest of researchers to examine the comparison of the implementation of football coaching management at the Darul Huda Islamic boarding school, Majak Ponorogo. 


\section{Review of Literatures}

Management is an activity process that is efficient, effective, and coordinated to maximize results. Husdarta (2011: 37) who argues that management is planning, organizing, leadership and evaluation. Management is closely related to the concept of organization. The organization is a forum that has a systematic work structure for common goals (Maulida, 2016). The main purpose of organizing is to organize all human and material resources into a certain work pattern in such a way that every person working and all material resources used are coordinated effectively and efficiently in achieving organizational goals as set out in the plan.

According to Jurdi (2018: 38) "human resource management is defined as a process and efforts to recruit, develop, motivate, and evaluate all human resources needed to achieve goals". The human resources referred to include all the people in the organization, namely those who are involved in the operationalization of the organization, from the lowest level to the top level.

Amiq (2014: 14) states that "In an effort to develop and improve sports achievement, one of them is properly and correctly programmed training." The main purpose of training is to form the skills or physical condition of athletes in order to achieve maximum performance. Harsono (2017: 50) explains that "Training is a systematic process of training or work, which is carried out repeatedly with increasing workload or work load." Training skills will be carried out in a structured and systematic manner to prepare for good performance.

Football is a sport using a ball played by two teams, each consisting of 11 (eleven) people. Football is a sport where a team tries to score as many goals as possible against the opponent's goal and prevent the opponent from scoring.

The aim of training in football in general is to improve performance optimally, while the specific objective is to improve the performance of movement, in this case, to improve the performance of skills in playing football. According to Hare, D (1992: 8) in detail the objectives of training are as follows: (a) developing personality, (b) conditions with the main goal of increasing power, speed and endurance, (c) improving technique and coordination of movements, (d) improve tactics, (e) improve mental. The main goal of athletes training is to reach the peak of their performance, so for that athlete coaching must be planned properly and correctly and be based on the concept of periodization and methodology and training principles.

The team's success in matches is determined by the team's success in training. Meanwhile, the team's success in training is largely determined by the extent to which the coach does the right training process. Broadly speaking, the training process is divided into stages: planning, preparation, implementation and evaluation. This process is a cycle that continues to rotate.

According to the Republic of Indonesia Law No.3 of 2005 on the National Sports System, "sports infrastructure is a place or space including the environment used for sports activities and or sporting activities. Meanwhile, sports facilities are equipment or equipment used for sports activities". Facilities are tools and equipment that support training activities, can be in permanent form such as buildings, fields, dormitories and other equipment used in training activities. Meanwhile, infrastructure includes facilities that indirectly support the training process.

Infrastructure or facilities are anything that is needed in physical activity, permanent or movable. The need for sports facilities and infrastructure in learning / training is very important, because in learning or training, the facilities and 
infrastructure that suit your needs must be used. In physical education learning, infrastructure is defined as something that makes the process easier or easier. One of the characteristics possessed by physical infrastructure is that it is relatively permanent or difficult to move. (Arman, 2014:2).

\subsection{Sports Coaching}

In the development of the world of sports, sports coaching is a very important factor in achieving the highest achievement, therefore the development of the world of sports depends on the development of the sport itself, both in community, school, as well as at the regional, national and even international levels. . Sports achievement itself is a measure of the success of coaching a well-developed or fostered sport. Sports achievement coaching is also not only in a sports club, sports coaching in schools also plays an important role with extracurricular activities.

Law, H (2013: 56) defines coaching as an art to facilitate performance, learning and other development, one of which is directly related to improving the performance of coaches and developing their skills. Coaching is an act, process, result, or better statement. coaching goals according to Stevens (2008: 78) are: (1) assisting clients in finding value or principle settings, (2) behavior, (3) life goals, (4) understanding about the world around them, (5) the level of involvement and how to discern choices that affect their experiences.

\subsection{Islamic Boarding School}

Pondok Pesantren is the oldest Islamic educational institution in Indonesia. Islamic boarding schools (pesantren) institutions play an important role in providing education for the Indonesian nation, especially religious education. The presence of Islamic boarding schools in the community is not only an educational institution, but also as a religious and socio-religious broadcasting institution. According to Zulhimma (2013), Islamic boarding schools are "traditional Islamic educational institutions to study, understand, deepen, appreciate and practice Islamic teachings by emphasizing the importance of religious morals as guidelines for daily behavior".

\section{Research Methods}

The research method used is descriptive qualitative research methods. Moleong (2013: 6) defines qualitative research as research that intends to understand the phenomena experienced by research subjects such as behavior, perception, motivation, action, etc., holistically and by means of descriptions in the form of words and language., in a special context which is natural and by making use of various scientific methods. Meanwhile, Sarosa (2012: 1) qualitative research is research that tries to understand phenomena in their natural setting and context (not in the laboratory) where the researcher does not attempt to manipulate the observed phenomena.

\section{Discussion}

In 2018-2019, the Persada team's achievements declined when participating in the National Santri League match. This resulted in the division of the main team into two, because at that time Darul Huda Mayak Islamic Boarding School received two invitations to football competitions and was demanded to field two teams. At the time of the national competition the Persada team tried to get another achievement. To get 
this achievement, of course, cannot be separated from the role of the human resources from the Islamic boarding school, including the management, coaches, and students (athletes). There are good training methods and programs, the availability of supporting facilities and infrastructure as well as funds in the football coaching process. Darul Huda Mayak is fully aware of the role of human resources as the subject of a source of value creation for the organization. Therefore, boarding school management is committed to continuing to develop HR competencies. Human resource development is directed at forming moral students who have integrity, knowledge and high skills through a competency-based HR development system. Competency-based HR development is the key to ensuring the long-term sustainability of the Persada team. The focus of Darul Huda Mayak Islamic boarding school is to build productive and innovative human resources who are able to contribute optimally to the achievement of club goals and objectives. In order to obtain competent human resources, it is necessary to pay attention to the tasks of human resource management. According to Harsuki (2013: 163), human resource management tasks include: human resource planning, employee recruitment, selection, socialization or orientation, training and development, performance appraisal, promotion, transfer, and demotion. The availability of human resources in the process of coaching the Persada football team consists of administrators, coaches and athletes. That the implementation of the training method for the development of football sports achievements at the Persada Darul Huda Mayak Ponorogo club is well programmed. This can be seen from the preparation of a written training program, the training schedule is in accordance with the national level training schedule, the division of periods from the short, medium and long term. With a wellprogrammed training method it can help the progress and development of the Persada Darul Huda Mayak Ponorogo football team athlete's performance. From the description above it can be concluded that the facilities and infrastructure owned by Darul Huda Mayak football club are very adequate. This can be seen from the availability of complete infrastructure provided by the Darul Huda Mayak Islamic Boarding School. With these very adequate facilities it facilitates the coaching process at the Darul Huda Mayak Islamic boarding school football club, especially making it easier for coaches to carry out training programs. Other facilities provided to athletes and coaches are in the form of dormitories, meals, salaries, and health facilities, because Darul Huda Mayak Islamic Boarding School also has its own health clinic. And from the facilities that make Darul Huda Mayak Islamic Boarding School athletes feel at home and want to remain passion to train to be the Darul Huda Mayak football club. that the funds allocated for the Darul Huda Mayak football club in carrying out coaching activities can be said to be very sufficient, because Darul Huda Mayak Islamic Boarding School is a large Islamic boarding school with thousands of existing students so that it can finance all the needs in the process of fostering the football achievements of Darul Huda Mayak Islamic Boarding School. Mr. Wahyudi as the daily administrator said "that from 2015-2019 there is a clear difference in funding, will but the biggest funding was issued when in 2017 and 2018, I can't say it was nominal, but there are reports every year, and when we need to file, it will be given ". Funds for training and competition operations come purely from the Islamic boarding schools managed by the Islamic boarding schools. The funds are used to support the implementation of Darul Huda Mayak football club programs. 


\section{Conclusion}

As a boarding school, Darul Huda Mayak Islamic Boarding School is committed to being able to carry out the responsibilities of the Islamic boarding school in facilitating students and has implemented the responsibilities of the Islamic boarding school, namely by providing guidance in various sports, one of which is the Persada Darul Huda Mayak football club Ponorogo. In terms of HR that Darul Huda Mayak hasSolid management and the large number of students who are interested in soccer, make the Persada football team easy to make commitments so that dismantling pairs of players for the needs of the team is very easy.

Darul Huda Mayak football has a coach who is licensed and has playing experience, so it is very competent to train the Persada Darul Huda Mayak Ponorogo academy with all its U-17 athletes. In addition, training plans and training programs are provided to athletes according to what the team needs. The coaches provide facilities to support the course of team training, such as fields and other supporting tools.

The seriousness of the Pondok in fostering its athletes, who are also students from the Darul Huda Mayak Ponorogo Islamic Boarding School, the Pondok provides whatever is needed by the Persada football team, so it must be fulfilled by the Pondok itself. Training equipment and the field are very much noticed by the lodge.

The management implementation from 2015-2020, both the management and the trainers has not changed and is very good. Transparency carried out by all management is very good. The compactness from the leader to the daily manager is very good. This is due to good communication, so that the information given from top to bottom or vice versa is conveyed well. However, athletes always undergo evaluation and regeneration. This aims to make the team better, as well as new prospective athletes to replace athletes who have graduated from Islamic boarding schools according to the team's needs.

In management, from 2015 to 2020 there is no change in management in management. However, changes in the players always change, considering that many students have graduated and have just entered the Darul Huda Mayak Ponorogo Islamic boarding school. Apart from changing the strategy, each year the coaches conduct an evaluation so that the Persada team gets good achievements. The trainers and coaches who have passed recruit new students.

Inside every Football teams, international, national and regional football teams have experienced ups and downs of achievement. After conducting the research, there was a decline in the Persada football team's performance due to the Persada team's weak ability in terms of penalties. In addition, some of the mainstay athletes from the Persada football team who at that time won the National Santri League in 2017. The decline in achievement was also due to the LSN (National Santri League) from 20182019, because the committee required the Persada football team to bring down 2 teams. Although the coach owned by Persada is competent to train the team, because he has experience playing in the arena professional and have licensed the Persada football team coaches. However, the limited number of coaches is one of the obstacles for the Persada team and it is divided into 2 teams which are required by the LSN (National Santri League) committee and the ability of Persada athletes is not yet maximized when making a penalty shootout. So that the Persada football team experienced a decrease in performance in the National Santri League. 


\section{References}

Ahmadi, Nuril. 2007. Panduan Olahraga Bolavoli. Surakarta: Era Pustaka Utama.

Amiq, Fahrial. 2016. Sepakbola Sejarah Teknik Dasar Persiapan Fisik Strategi dan Peraturan Permainan. Malang: Universitas Negeri Malang. 2014. Futsal Sejarah Teknik Dasar Persiapan Fisik Strategi Dan Peraturan Permainan. Malang: Universitas Negeri Malang.

Arman. 2014. Survei Sarana Prasarana Olahraga Dengan Efektifitas Pembelajaran Penjasorkes SMP Negeri Kecamatan Dampal Selatan Kabupaten Toli-Toli. Jurnal Tandulako Vol. 2 No 6 Hal, 1-15

Bhyantari, N.P.R., Muliarta, I.M. 2016. Kapasitas Aerobik Mahasiswa Pemain Wushu Lebih Baik Daripada Mahasiswa Bukan Pemain Wushu Di Universitas Udayana. EJurnal Medika Udayana, 5(5): 1-8.

Budiwanto. 2004. Pengetahuan Dasar Melatih Olahraga. Malang: Depdiknas Universitas Negeri Malang. 2012. Metodologi Latihan Olahraga. Malang: UM Press.

Bompa, T. O. \& Haff, G. 2009. Theory and Methodology Of Training. Kendal/hun: Human Kenetics.

Centhini, S, \& Russel T. 2009. Buku Pintar Sepakbola. Jakarta: Penerbit Inovasi.

Danurwindo, Putera, G., Sidik, B., Prahara, JK. 2017. Kurikulum Pembinaan Sepakbola Indonesia. Jakarta: Persatuan Sepakbola Seluruh Indonesia.

Falah, Abdul. 2013. Pelaksanaan Pembinaan Prestasi Olahraga Sepak Bola di SMA NU Al Ma'ruf Kudus. TESIS. Surakarta: Universitas Sebelas Maret.

Firzani, Hendri. 2010. Segalanya Tentang Sepak Bola. Jakarta: Erlangga.

Ferdiana, I., Muhammad, Wiriawan, O. (2020). Effect of Exercise Countermovement Jump and Depth Jump against the Increase Agility and Leg Muscle Power. Budapest International Research and Critics in Linguistics and Education (BirLE) Journal Vol 3 (4): 2259-2273.

Haedari, Amin \& El-Saha, Ishom. 2004. Panorama, Pesantren Dalam Cakrawala Modern. Jakarta: Diva Pustaka.

Hare, D. 1992. Principle of Sport Training. Berlin: Sportverlag.

Haris, M.A., Doewes, M., and Liskustyawati, H. (2020). Development of Boccia Cerebral Palsy's National Athlete Achievement in the Indonesian National Paralympic Committee. Budapest International Research and Critics in Linguistics and Education (BirLE) Journal Vol 3 (2): 784-794.

Harsuki. 2013. Pengantar Manajemen Olahraga. Jakarta: PT Raja Grafindo Persada.

Harsono. 2017. Kepelatihan Olahraga Teori dan Metodologi. Cetakan-2. Bandung: PT Remaja Rosdakarya. 2001. Latihan Kondisi Fisik. Bandung: FPOK UPI.

Hidayatullah, MF. 2002. Pembelajaran Pendidikan Jasmani Bagi Anak dengan Kebutuhan Pendidikan Khusus: Tinjauan Terhadap Aspek-aspek yang Belum Mendapat Penekanan. Jurnal Rehabilitasi dan Remidiasi PPRR Lembaga Penelitian UNS, Vol 13, No. 1.

Husdarta. 2009. Sejarah dan Filsafat Olahraga. Bandung: Alfabeta. . 2011. Manajemen Pendidikan Jasmani. Bandung: Alfabeta.

Irianto, DP. 2002. Dasar Kepelatihan. Yogyakarta: IKIP Yogyakarta.

Jurdi, Fatahullah. 2018. Manajemen Sumber Daya Manusia: strategi Pengelolaan SDM Berkualitas dan Berdaya Saing. Malang: Intrans Publising.

Depdiknas. 2002. Kamus Besar Bahasa Indonesia. Jakarta: Balai Pustaka. 
Khasan N.A., Rustiadi T. \& Annas M. 2012. Korelasi Denyut Nadi Istirahat dan Kapasitas Vital Paru Terhadap Kapasits Aerobik. Journal of Physical Education, Sport, Health and Recreations, 1(4): 162-163.

Law, Ho. 2013. The Psychology of Coaching, Mentoring and Learning. Second Edition. John Wiley \& Sons, Ltd., UK.

Lubis. 2013. Panduan Praktis Penyusunan Program Latihan. Jakarta: Rajawali Press.

Lutan, Rusli. 2000. Dasar-Dasar Kepelatihan. Depdiknas

Ma’u, M \& Santoso. 2014. Teknik Dasar Bermain Sepak Bola. Yogyakarta: Cakrawala.

Maulida. 2016. Pembinaan Prestasi Bolavoli Di Klub Ivolta Kecamatan Saronggi Kabupaten Sumenep. Jurnal Kesehatan Olahraga Vol. 06 No 2426-432.

Muhajir. 2007. Pendidikan Jasmani, Teori dan Praktek. Jakarta: Erlangga.

Mangolo, E.W., and Makadada, F.A. (2020). The Relationship between Hand Grip Strength and the Accuracy of Field Tennis Services in Eighth Semester Male Students in Department of Training Faculty of Sports Science UNIMA.

Budapest International Research and Critics in Linguistics and Education (BirLE) Journal Vol 3 (2): 1220-1239.

Mutohir, T.C., \& Maksum, A. 2007. Sport Development Index, Alternatif Baru Mengukur Kemajuan Pembangunan Bidang Keolahragaan. Jakarta: PT Indeks.

Mutohir, TC, dkk. 2011. Berkarakter Dengan Berolahraga Berolahraga Dengan Berkarakter Olahraga. Surabaya: SPORT Media.

Moleong, Lexy .2013. Metode Penelitian Kualitatif. Bandung: Remaja Rosdakarya.

Nawawi, H. 2001. Manajemen Sumber Daya Manusia Untuk Bisnis yang Kompotitif. Cetakan Keempat. Yogyakarta: Gajah Mada, University Press

Nizar, S. 2007. Sejarah Pendidikan Islam. Jakarta: Prenada Media.

Patusuri, Achmad. 2012. Manajemen Pendidikan Jasmani dan Olahraga. Jakarta: Rineka Cipta.

Priyanto, Hidayah, Nugroho. 2014. Model Pembinaan Prestasi Olahraga Voli Pantai di Kabupaten Indramayu Tahun 2013. Journal of Sport Sciences and Fitnesis 3(1).

PSSI. 2009. Buku Panduan Cabang Olahraga Sepakbola Special Olympics. Pengurus Pusat Special Olympics Indonesia.

Putra, RA. 2016. Analisis Pembinaan Prestasi Cabang Olahraga Sepakbola di Akademi Triple's U-17 Kabupaten Kediri. Jurnal Kesehatan Olahraga, Vol. 06 No. 2 hal 433440.

Roesdiyanto \& Sudjana, IN. 2012. Sejarah Olahraga dan Pendidikan Jasmani Cetakan 3. Malang: Universitas Negeri Malang (UM Press).

Rukiati, EK \& Hikmawati, F. 2006. Sejarah Pendidikan Islam di Indonesia. Bandung: Pustaka Setia.

Rusli. 2015. Analisis Pembinaan Olahraga Pelajar Kabupaten Pidie Jaya Jaya Jaya. Jurnal Sport Pedagogy Vol. 5. No. 1.

Sari, DR., Tangkudung, dan Hanif. 2018. Evaluasi Program Pemusatan Latihan Daerah (Pelatda) Bolavoli Pasir Putri Dki Jakarta. Jurnal Ilmiah Sport Coaching and Education, Vol. 2.

Sarosa, S. 2012. Penelitian Kualitatif: Dasar-Dasar. Jakarta: PT Indeks.

Scheunemann, T., Reyna, C., Perez, Gunadi, P., Ibo, M., Sugiri, H. 2012. Kurikulum Sepak Bola Indonesia: Untuk Usian Dini (U5-U12), Usia Muda (U13-U20) \& Senior. Persatuan Sepakbola Seluruh Indonesia.

Setiawan, Ebta. 2010-2013. Kamus Besar Bahasa Indonesia. Offline Versi 1.5. Freeware

Soepartono. 2000. Sarana dan Prasarana Olahraga. Jakarta: Departemen Pendidikan dan Kebudayaan. 
Stevens, Nicola. 2008. Learning to Coach. For Personal and Professional Development. Oxford, United Kingdom: How To Bokks Ltd.

Subarjah, Herman. 2008. Administrasi Pendidikan Jasmani dan Organisasi Olahraga. Jakarta: Universitas Terbuka.

Sucipto. 2000. Sepakbola. Jakarta: Departemen Pendidikan dan Kebudayaan

Sugiyono. 2014. Metode Penelitian Manajemen. Bandung: Alfabeta.

Sukadiyanto. 2011. Pengantar Teori Dan Metodologi Melatih Fisik. Bandung: CV. Lubuk Agung.

Sulipan. 2007. Manajemen Sekolah. (http//geocities.com).

Suparyadi. 2015. Manajemen Sumber Daya Manusia: Menciptakan Keunggulan Bersaing Berbasis Kompetensi SDM. Yogyakarta: Andi.

Tohar. 2002. Ilmu Kepelatihan lanjut. Semarang: FIK Unnes.

Undang-Undang No.3 Tahun 2005. Tentang Sistem Keolahragaan Nasional. Jakarta: Kementrian Negara Pemuda dan Olahraga.

Wibowo, Kristianto. 2017. Evaluasi Pembinaan Prestasi Olahraga Bola Basket di Kabupaten Magetan. TESIS. Surakarta: Universitas Sebelas Maret.

Yunus, M. 2013. Dasar-Dasar Bermain Sepakbola. Malang: Universitas Negeri Malang.

Zulhimma. 2013. Dinamika Perkembangan Pondok Pesantren di Indonesia. Jurnal Darul 'Ilmi, Vol. 01, No. 02. 